\title{
FALSAFAH SAINS ISLAM DAN PEMBENTUKAN KARAKTER ILMUAN
}

\author{
Azizan Ahmad \\ E-mail : azizan@ukm.my \\ Universiti Kebangsaan Malaysia
}

\begin{abstract}
In theory, philosophy of science Islam has also developed along the Islamization of science demands. But to fight for the Islamic philosophy of science as a discipline that should be taught to students homage to science, still as a pre-requisite, and not as a mainstream agenda learning Faculty. Challenges and expectations requires a paradigm and a distinctive epistemology that leads to the conceptualization entrepreneurship sciencebased philosophy of science. The study used a set of questions inquired which consist of 6 Courant. The first portion consists rather than edict background of the respondents, when the second portion comprised of Scale interests and behavior towards the philosophy of science, scale philosophy attitudes toward science, philosophy of science knowledge scale, scale interests and behavior towards entrepreneurship and scale of attitudes toward entrepreneurship. By using multiple regression test, schedule 3 regression model showed a significant effect of interest and behavior towards the philosophy of science and philosophy of science knowledge to philosophy Attitudes toward science, in which the value of $F=70708$ at $p<0.05$. The regression model, the predictor variables contributed by $26.9 \%$ to over philosophy attitude toward science. When seen the power of each predictor variable, which gives the impression of dominance is the highest on a scale of interest and behavior towards the philosophy of science $(t=8208)$, the philosophy of science versus Knowledge scale $(t=6,905)$.
\end{abstract}

Key words : Philosophy of Islamic Science and entrepreneurship

\section{PENDAHULUAN}

Dalam konteks sejarah, potensi akal manusia telah dibahas oleh hampir seluruh pelbagai cabang ilmu, apakah ilmu sosial, agama mahupun sains. Akal merupakan intelek yang membuat manusia mampu berfikir untuk mengetahui diri dan alam sekitamya. Akal bersifat dinamis dan berkembang dengan melahirkan ilmu dan teknologi secara sedar dan sistematik. Bila dilihat secara fizikal, volume akal atau otak kecil manusia (serebelum) adalah sebanyak $1000 \mathrm{cc}$. dan hanya manusia satu-satunya makhluk Allah yang memiliki sebanyak volume tersebut. Dan Allah menciptakan akal adalah sebagai sarana untuk berfikir tentang kebesarannya. 
Islam yang berpandukan kitab suci Al Qur'an menekankan sebuah prinsip universal bahawa manusia adalah sebaik-baik penciptan dan makhluk yang sempurna (QS, at thin; 5). Penciptaan manusia yang sempurna disebut Allah dalam al Qur'an sebagai khalifah di muka bumi (QS, al baqarah; 30), dengan diiringi oleh tiga anugerah yang diberikan Allah sebagai pemangku khalifah, iaitu : pertama diberi fizikal dan akal yang sempurna. Kedua diberikan agama dan ketiga dianugerahkan alam semesta untuk keperluan hidupnya. Ketiga-tiga anugerah ini merupakan ciri penting manusia sebagai makhluk yang memiliki peradaban. Peradaban tidak akan terbentuk tanpa kekuatan akal, agama dan alam, sebagai potensi untuk menghasilkan pelbagai output-output peradaban.

Manakala agama dengan idea utama yang paling sentral adalah mentauhidkan dan meyakini Allah sebagai satu-satunya Tuhan yang patut disembah- memberikan sistem nilai terhadap seluruh dimensi kehidupan manusia. Adapun agama dan kitab suci yang hak turun daripada Allah mencirikan lima sistem nilai yang terkandung di dalamnya: 1). Tauhid kepada Allah. 2).Perundang undangan (Syariat). 3). Ilmu pengetahuan. 4). Sejarah. 5). Falsafah.

Oleh itu dunia pendidikan diharapkan mampu untuk menyiapkan dan menyediakan generasi yang berkualiti, berfikiran kreatif, dan mempunyai kemampuan inovatif hingga boleh memberikan kontribusi kepada pembangunan negara dan agama. Sains dan teknologi merupakan bidang yang amat penting dalam menentukan pembangunan dan kemajuan sesebuah negara. Kepentingan bidang ini bukan sahaja membolehkan sesebuah negara mampu bersaing dalam bidang ekonomi secara global, akan tetapi juga dimanfaatkan dalam segenap aspek kehidupan seharian. Penguasaan sains dan teknologi mampu memberikan pulangan yang lumayan kepada banyak aspek kehidupan. Justru itu, langkah bijak dalam proses pendidikan yang berasaskan pengetahuan dan kemahiran serta teknologi perlu mendapat perhatian demi kemajuan dan kesejahteraan sesebuah negara. Untuk mewujudkan perkara yang demikian pun perlu sokongan dari pelbagai pihak dalam bentuk moril mahupun materil, hingga halatuju dan matlamat negara tercapai sesuai dengan yang kita hasratkan.

Malaysia merupakan negara sedang berkembang, pesat membina dalam usaha memacu halatuju negara, oleh itu perlu sokongan daripada sumber manusia yang berkualiti. Sumber manusia perlu diperkembangkan secara menyeluruh dan bersepadu untuk melahirkan modal insan yang berkualiti. Perkara ini boleh dicapai melalui sistem pendidikan. Pendidikan itu sendiri merupakan suatu agensi terpenting dalam proses pembinaan bangsa (Shahabuddin, Rohizani dan Mohd Zohir, 2003). Sains melandasi perkembangan teknologi, sedangkan teknologi menunjang perkembangan sains, Sains terutama digunapakai untuk aktiviti- 
aktiviti discovery dalam upaya memperolehi penjelasan tentang objek dan fenomena alam, namun juga untuk aktiviti penemuan.

Pengembangan sains ini tidak selalu dihubungkaitkan dengan aspek kepentingan masyarakat. Sedangkan teknologi, merupakan aplikasi sains yang terutama dalam kegiatan inovasi, berupa alat-alat atau barang untuk memenuhi keperluan masyarakat. Pengembangan teknologi selalu berhubungkait dengan kepentingan masyarakat. Oleh yang demikian, sains, teknologi dan masyarakat merupakan bahagian yang tidak terpisahkan (Poedjiadi, 1990 ; Yager, 1992: 4). Selain itu Sukmadinata (1997) pun mengatakan bahawa beberapa sifat penting daripada pendidikan, dua diantaranya adalah: (1) Pendidikan diarahkan pada kehidupan masyarakat. Pendidikan yang dilaksanakan oleh pemerintah mahupun pihak swasta sebenanya diadakan untuk menyiapkan pelajar di dalam kehidupan masyarakat. (2) pelaksanaan pendidikan dipengaruhi dan disokong oleh persekitaran masyarakat tempat pendidikan itu berlangsung. Pernyataan tersebut mengisyaratkan kedudukan penting daripada masyarakat di dalam proses pendidikan, baik di dalam perencanaan pendidikan seperti pengembangan kurikulum, mahupun di dalam pelaksanaan seperti dalam pelbagai sokongan. Selari dengan pengembangan kurikulum, pernyataan ini juga menyiratkan perlunya kurikulum yang diperkembangkan bersandar pada sistem social budaya masyarakat tempatan.

Falasafah Sains Islam merupakan mata pelajaran teras di peringkat sekolah menengah yang bertujuan untuk melahirkan pelajar yang memiliki pengetahuan dan kemahiran sains, kemahiran berfikir serta mampu mengaplikasikan pengetahuan dan kemahiran berlandaskan sikap saintifik. Mata pelajaran sains di Malaysia sudah diajarkan mulai dari sekolah rendah secara berintegrasi kedalam mata pelajaran lain (seperti bahasa Melayu, bahasa Inggris dan matematik), sampai kepada sekolah menengah atas secara khusus atau dikenali sebagai monolitik ertinya mata pelajaran sains seperti fizik, biologi, dan kimia mempunyai kurikulum dan masa bersemuka secara bersendiri.

\section{Sains Dan Keusahawanan}

Kegagalan mencapai matlamat ekonomi bumiputera melalui Dasar Ekonomi Baru (DEB) mencetuskan transformasi dasar ekonomi negara kepada Model Ekonomi Baru (MEB) yang dilancarkan oleh Datuk Seri Mohd. Najib Tun Abdul Razak. (Mingguan Malaysia, 28 Mac 2010). Perubahan ini penting kerana cabaran globalisasi semakin sengit, setelah model ekonomi dunia berubah dari ekonomi yang berasaskan barangan (P-ekonomi) bertukar kepada ekonomi berasaskan ilmu (K-ekonomi) (Hashim \& Abd. Jalil 2007). 
Selaras dengan keperluan Model Ekonomi Baru, semua program pendidikan yang menepati ciri dan kehendak model berkenaan perlu diwujudkan supaya kita mampu melahirkan generasi yang kreatif, inovatif dan dinamik (Ibrahim, 2010). Usaha ini sangat penting untuk melonjakkan pencapaian anak bangsa bukan sahaja dalam bidang akademik atau pun kemahiran, malahan yang lebih penting adalah untuk melahirkan insan kamil yang mampu menunjangi kemajuan negara pada masa hadapan (Ibrahim 2010).

Kurikulum sekolah masa kini patut menggunakan strategi pengajaran menggabungjalinkan proses penelitian saintifik (scientific research) dan proses penelitian pemasaran (market research) yang merupakan satu aspek penting dalam keusahawanan (Nor Aishah, 2001). Aktiviti pembelajaran berasaskan penyelesaian masalah yang mengintegrasikan orientasi keusahawanan akan dapat melatih pelajar untuk mencari idea-idea untuk menyelesaikan sesuatu masalah secara kreatif (Lilia et al. 2003).

Majelis Amanah Rakyat (MARA), agensi kerajaan yang berperanan untuk menggalakkan, membimbing, melatih dan membantu bumiputera menyertai dengan aktif dan maju dalam kegiatan perdagangan dan perindustrian, telah mewujudkan Maktab Rendah Sains MARA (MRSM) sebagai landasan untuk mencapai hasrat kerajaan untuk membangunkan modal insan bumiputera yang cemerlang dalam bidang Sains, Teknologi dan Keusahawanan (MARA, 1990). Memandangkan sistem pendidikan MRSM yang berfokuskan kepada pendidikan Sains dan Keusahawanan maka bolehlah dianggapkan bahawa MRSM merupakan tapak semaian paling sesuai untuk mengimplimentasikan kurikulum pendidikan Sains dan Teknologi yang berasaskan keusahawanan.

Kurikulum Sains semasa belum lagi menjadikan pemikiran keusahawanan, kemahiran berinovasi dan mereka cipta produk sebagai sebahagian dari objektif pendidikan Sains. Maka bolehlah diandaikan bahawa pelajar-pelajar Sains mempunyai kemahiran yang terbatas bagi tujuan untuk mengintegrasi pemikiran keusahawanan dalam pendidikan Sains. Lilia Halim, Nor Aishah Buang dan Khalijah Mohd. Salleh. (2003) mencadangkan penelitian perlu dibuat untuk melihat sejauh mana kefahaman dan keperluan pelajar mengenai pemikiran Sains Keusahawanan, pengaruh sosiobudaya dan nilai terhadap pembangunan reka cipta dan inovasi merentasi kurikulum dan juga semua peringkat pendidikan.

\section{Permasalahan Penelitian}

Tujuan pendidikan sains tidak hanya untuk mempertingkatkan kefahaman terhadap dunia sains itu sendiri (science for science), tetapi yang lebih penting jugs adalah bagaimana memahami kehidupan manusia 
secara keseluruhan (AAAS, 1989), dan mempertingkatkan tanggung jawab sosial (Cross \& Price, 1992).

Pengpenelitian sains haruslah terangkum dalam konteks Persekitaran budaya dan iklim pembelajaran yang memenuhi aspek-aspek falsafah dan sejarah sains. Karena falsafah sains dan sejarah sains ini akan dapat membentuk norms, nilai dan kepercayaan pelajar dalam membidangi sains dan teknologi ini. Falsafah sains boleh mencerminkan cara pelajar berfikir dan bertindak. Sayugiyanya falsafah sains menjadi sebahagian daripada mata kuliah, yang akan memberikan implikasi keseluruhan interaksi dinamik dalam persekitaran budaya sama ada dari aspek fizikal, akademik, mahupun psikososial (Haynes 2001).

Falsafah sains juga diharapkan sebagai Motivasi akademik dan strategi pembelajaran yang akan berperanan penting dalam menjayakan pelajar dalam masa hadapannya. Sehingga akan terlahirlah para sarjana yang memiliki motivasi dan dedikasi yang tinggi sebagai seorang saintis.

Pintrich (2003) telah mengupas peranan motivasi pelajar dalam konteks pengajaran dan pembelajaran dari perspektif sains. Beliau mengetengahkan secara umum yang perlu dimasukkan apabila seseorang pengkaji mahu membuat penelitian tentang motivasi, iaitu penelitian yang menggunakan pendekatan saintifik yang bermaksud generalisasi yang di buat hasil dapatan sesuatu penelitian perlu disokong oleh bukti empirik selari dengan teori dan konsep tentang motivasi akademik pelajar.

Pada prinsipnya falsafah dan sejarah sains adalah asas pembelajaran biologi, mata pelajaran fizik, dan mata pelajaran kimia, yang akan dapat menghungkaitkan dengan fenomena alam semulajadi dan pengetahuan harian. Dengan ini pelajar dapat diharapkan boleh menguasai kemahiran berfikir dan kemahiran saintifik disamping boleh mengamalkan sikap saintifik dan boleh menilai maklumat berkenaan dengan sains dan teknologi secara bijak dan berkesan. Menghargai sumbangan sains dan teknologi terhadap pembangunan negara untuk kesejahteraan manusia sejagat melalui penyelidikan sains adalah usaha manusia berasaskan kemampuan akal fikiran dalam memahami fenomena alam kearah mencapai matlamat kesejahteraan manusia sejagat melalui objektif yang disasarkan terhadap para pelajar (Zaharah 2009).

Sistem pendidikan berasaskan falsafah sains ini juga menyangkut aspek-aspek kompetensi iaitu mengutamakan kemahiran, sikap dan pencapaian selari dengan kurikulum yang digunapakai. Sikap (Lilia et al 2002) dan pedagogi berkesan (Abd Rafie. 2002) merupakan antara aspek yang sering dikaitkan dengan pencapaian pelajar dalam mata pelajaran sains. Pengajaran dan pembelajaran yang kurang memuaskan pelajar perlu diatasi segera. Zurida et al. (2005) menyarankan para pelajar agar memahami strategi pengajaran dan pembelajaran yang sesuai bagi 
konsep-konsep sains. Maka falsafah sains diharapkan dapat sebagai salah satu aspek yang akan meningkatkan strategi untuk lebih meningkatkan pencapaian pleajar dalam bidang studi sains dan teknologi ini.

Perubahan konsep ilmu yang radikal pun telah berlaku dari semasa ke semasa juga boleh mempengaruhi cara berfikir dan secara keseluruhan memacu perkembangan ilmu sampai tedadinya revolusi industri pads abad ke-19. Atas perkara ini diperlukan suatu konsepsi ilmu pengetahuan moden yang berasaskan suatu budaya berfikir yang seimbang antara penguasaan sains dan tekhnologi dengan nilai-nilai yang terkandung dalam sains dan teknologi dimaksud. Kerana bagaimanapun sians dan teknologi tidak dapat dipisahkan dengan nilai.

Disamping itu perpektif keusahawanan harus juga disalarikan dengan mata kuliah falsafah dan sejarah sains, hal disebabkan perubahan dalam inovasi yang sangat pesat berkembang, pelajar perlu bersedia terlebih dahulu untuk meningkatkan pengetahuan keusahawanan dan menguasai teknologi semasa. Memandangkan penelitian ini berfokuskan kepada pelajar Sains di MRSM, untuk itu penelitian ini adalah lebih spesifik untuk menilai sejauh mana, tahap pemikiran Sains Keusahawanan pelajarpelajar Sains di MRSM. Ini kerana golongan inilah akan menjadi penyumbang utama ke atas pembentukan masyarakat Perdagangan dan Perindustrian Bumiputera selaras dengan hasrat transformasi ekonomi Negara (Ibrahim, 2010).

Sifat kemahiran proses sains yang generik tidak terhad kepada disiplin Sains tabii sahaja. Kelebihan pengetahuan dan kemahiran proses sains memudahkan seseorang itu memproses sesuatu bahan mentah kepada sesuatu yang berfaedah dalam kehidupan melalui teknologi. Poh Swee Hiang (1996) berpendapat bahawa kemahiran proses Sains pada prinsipnya boleh digunakan dalam semua bidang ilmu untuk memahami sesuatu fenomena dan mendapatkan keputusan atau penyelesaian masalah. Jika seseorang penyelidik menggunakan kemahiran proses Sains dalam konteks inovasi dan kreativiti untuk mencipta sesuatu produk yang boleh dikomersialkan, penyelidik ini dikatakan mempunyai pemikiran Sains Keusahawanan (Lilia et al. 2003). Merujuk kepada Peter dan Anne (2000) mereka menyatakan bidang kemahiran proses Sains dan pemikiran keusahawanan ini mempunyai orientasi yang sama. Model Proses Penyelesaian Masalah oleh Lilia et al. (2003) menerangkan dengan jelas bagaimana terdapat persamaan orientasi dalam kedua-dua bidang ini.

Dengan adanya integrasi antara ilmu Sains dan Keusahawanan hasil akhir yang boleh didapati ialah pembentukan idea/produk baru dan seterusnya ini dapat menjana pekerjaan, kekayaan dan manfaat sama ada untuk individu, masyarakat seterusnya kepada negara (Robiah, 1998 \& Nor 
Aishah dan Siti Rahaya, 1998). Untuk merealisasikan pendekatan pengajaran Sains Keusahawanan seseorang perlulah terlebih dahulu menjadikan sifat inovasi sebagai cirinya (Mohd. Azhar et al. 2003). pelajar perlu mempunyai perspektif yang luas, bersifat dinamik dan mampu menyeronokkan pengajaran. Untuk menjadikan pengajaran dan pembelajaran Sains lebih menarik dan berkesan, pelajar harus bertindak sebagai fasilitator, berfikiran terbuka, imaginatif, kreatif, inovatif dan inventif. Peluang hendaklah diberikan sepenuhnya kepada pelajar dalam mengembangkan bakat mereka (Renzulli, Rizza dan Smith 2002).

\section{Metode penelitian}

Penelitian ini merupakan satu penelitian yang bersifat tinjauan dengan menggunakan soal selidik yang diedarkan kepada subjek untuk dijawab. Pentadbiran soal selidik ini bertujuan untuk melihat profil minat dan tingkah laku terhadap falsafah saians dalam kalangan mahasiswa prasiswazah sains dan tekhnologi UKM. Penelitian yang melibatkan seramai 388 responden mahasiswa prasiswazah ini, dijalankan di Fakulti sains dan tekhnologi universiti kebangsaan Malaysia. Responden diambil dari pada setiap program dan jabatan yang dipilih secara persampelan rawak sistematik.

\begin{tabular}{|c|c|c|c|}
\hline \multicolumn{4}{|c|}{$\begin{array}{l}\text { Alat ukur penelitian } \\
\text { Jadual } 1 \quad \text { Senarai Alat Instrumen Kajian }\end{array}$} \\
\hline Pemboleh Ubah & Alat Pengukuran & Pereka / tahun & $\begin{array}{l}\text { Jumlah } \\
\text { item }\end{array}$ \\
\hline $\begin{array}{l}\text { Minat Dan } \\
\text { Tingkah Laku } \\
\text { Terhadap } \\
\text { Falsafah Sains }\end{array}$ & $\begin{array}{l}\text { Sakala Minat Dan } \\
\text { Tingkah Laku Terhadap } \\
\text { Falsafah Sains }\end{array}$ & Azizan (2011) & 5 \\
\hline $\begin{array}{l}\text { Sikap Terhadap } \\
\text { Falsaf Sains }\end{array}$ & $\begin{array}{l}\text { Skala Sikap Terhadap } \\
\text { Falsaf Sains }\end{array}$ & Azizan (2011) & 10 \\
\hline $\begin{array}{l}\text { Pengetahuan } \\
\text { Falsafah Sains }\end{array}$ & $\begin{array}{l}\text { Skala Pengetahuan } \\
\text { Falsafah Sains }\end{array}$ & Azizan (2011) & 11 \\
\hline $\begin{array}{l}\text { Minat Dan } \\
\text { Tingkah Laku } \\
\text { Terhadap } \\
\text { Keusahawanan }\end{array}$ & $\begin{array}{l}\text { Skala Minat Dan } \\
\text { Tingkah Laku Terhadap } \\
\text { Keusahawanan }\end{array}$ & Azizan (2011) & 11 \\
\hline $\begin{array}{l}\text { Sikap Terhadap } \\
\text { Keusahawanan }\end{array}$ & $\begin{array}{l}\text { Skala Sikap Terhadap } \\
\text { Keusahawanan }\end{array}$ & Azizan (2011) & 8 \\
\hline
\end{tabular}




\section{Kaedah analisis data}

Data dianalisis menggunakan statistik deskriptif dan inferensi. Statistik deskriptif untuk pemerihalan pemboleh ubah sama ada dari segi min, mahupun peratusan. Analisis Statistik inferensi pula adalah untuk menguji hipotesis yang dibina melalui ujian $t$ dan ANOVA, dalam paras $p<0.05$ yang menggunakan SPSS versi 20.

\section{Dapatan Penelitian}

Dari jadual 1 memperlihatkan responden lelaki seramai 78 orang (20.1\%) dan perempuan seramai 310 orang (79.9\%). Responden bangsa melayu seramai 272 orang $(70.1 \%)$, india seramai 16 orang $(4.1 \%)$, cina seramai 88 orang $(22.7 \%)$ dan lain-lain seramai 12 orang $(3.1 \%)$. Responden beragama Islam seramai 279 orang (71.9\%), kristian seramai 13 orang $(3.4 \%)$, hindu seramai 14 orang $(3.6 \%)$ dan buddha seramai 82 orang $(21.1 \%)$. Responden mahasiswa yang berasal dari bandar seramai 216 orang $(55.7 \%)$ dan luar bandar seramai 172 orang (44.3\%).

Jadual 1. Kekerapan Responden Mengikut Faktor Demografi

\begin{tabular}{llrr}
\hline Pemboleubah & Kumpulan & f & $\mathbf{( \% )}$ \\
\hline Jantina & Lelaki & 78 & 20.1 \\
& Perempuan & 310 & 79.9 \\
\hline Bangsa & Melayu & 272 & 70.1 \\
& India & 16 & 4.1 \\
& Cina & 88 & 22.7 \\
& Lain-Lain & 12 & 3.1 \\
\hline Agama & Islam & 279 & 71.9 \\
& Kristian & 13 & 3.4 \\
& Hindu & 14 & 3.6 \\
& Buddha & 82 & 21.1 \\
\hline Mastautin & Bandar & 216 & 55.7 \\
& Luar Bandar & 172 & 44.3 \\
\hline Tahap Umur & 21 tahun ke bawah & 313 & 81.1 \\
& 22 tahun ke atas & 73 & 18.9 \\
\hline Kelayakan & STPM & 93 & 24.0 \\
Akademik & Matrikulasi & 256 & 66.0 \\
& Diploma & 13 & 3.4 \\
& Lain-Lain & 26 & 6.7 \\
\hline Tahun & Tahun1 & 87 & 22.8 \\
Pengajian & Tahun 2 & 224 & 58.6 \\
& Tahun 3 & 71 & 18.6 \\
\hline Latarbelakang & Sekolah Menengah & 227 & 58.5 \\
Sekolah & Sekolah Menengah Agama & 46 & 11.9 \\
& Sekolah Menengah & 89 & 22.9 \\
& Kebangsaan & & \\
& Lain-Lain & 26 & 6.7 \\
\hline & & &
\end{tabular}


Responden yang berumur 21 tahun ke bawah seramai 313 orang $(81.1 \%)$ dan 22 tahun ke atas seramai 73 orang (18.9\%). Responden dengan kelayakan STPM seramai 93 orang $(24.0 \%)$, matrikulasi seramai 256 orang $(66.0 \%)$, Diploma seramai 13 orang $(3.4 \%)$ dan lain-lain seramai 26 orang $(6.7 \%)$. Responden tahun 1 seramai 87 orang $(22.8 \%)$, tahun 2 seramai 224 orang $(58.6 \%)$ dan tahun 3 seramai 71 orang $(18.6 \%)$. Responden mengikut latarbelakang sekolah lulusan sekolah menengah seramai 227 orang (58.5\%), sekolah menengah agama seramai 46 orang $(11.9 \%)$, sekolah menengah kebangsaan seramai 89 orang $(22.9 \%)$ dan lain-lain seramai 26 orang $(6.7 \%)$.

Jadual 2. Korelasi matriks di antara pembolehubah

\begin{tabular}{|c|c|c|c|c|}
\hline Pembolehubah & $\begin{array}{c}\text { Sikap } \\
\text { terhadap } \\
\text { falsafsah } \\
\text { sains }\end{array}$ & $\begin{array}{l}\text { Pengetahuan } \\
\text { falsafah sains }\end{array}$ & $\begin{array}{c}\text { Minat dan } \\
\text { tingkah laku } \\
\text { terhadap } \\
\text { keusahawana } \\
n\end{array}$ & $\begin{array}{c}\text { Sikap } \\
\text { terhadap } \\
\text { keusahawa } \\
\text { nan }\end{array}$ \\
\hline $\begin{array}{l}\text { Minat dan tingkah laku } \\
\text { terhadap falsafah sains }\end{array}$ & $.422^{* *}$ & $.188^{* *}$ & $.385^{* *}$ & $.263^{*+}$ \\
\hline $\begin{array}{l}\text { Sikap terhadap } \\
\text { falsafsah sains }\end{array}$ & - & $.375^{* *}$ & $.386^{* *}$ & $.403^{* *}$ \\
\hline $\begin{array}{l}\text { Pengetahuan falsafah } \\
\text { sains }\end{array}$ & - & - & $.235^{* *}$ & $.361^{* *}$ \\
\hline $\begin{array}{l}\text { Minat dan tingkah laku } \\
\text { terhadap } \\
\text { keusahawanan }\end{array}$ & - & - & - & $.470^{* * *}$ \\
\hline
\end{tabular}

Berdasarkan hasil ujian korelasi dalam jadual 2 memperlihatkan terdapat hubungan antara Minat dan tingkah laku terhadap falsafah sains dengan Sikap terhadap falsafsah sains, dimana nilai $r=.422^{* *}$ dengan $p<0.05$. Begitu juga hasil ujian korelasi di atas memperlihatkan terdapat hubungan antara Minat dan tingkah laku terhadap falsafah sains dengan Pengetahuan falsafah sains $\left(r=.188^{* *}\right)$, terdapat hubungan antara Minat dan tingkah laku terhadap falsafah sains dengan Minat dan tingkah laku terhadap keusahawanan $\left(r=.385^{* *}\right)$, terdapat hubungan antara Minat dan tingkah laku terhadap falsafah sains dengan Sikap terhadap keusahawanan $\left(r=.263^{* *}\right)$.

Berdasarkan hasil ujian korelasi di atas memperlihatkan terdapat hubungan antara Sikap terhadap falsafsah sains dengan Pengetahuan falsafah sains, dimana nilai $r=.375^{* *}$ dengan $p<0.05$. Begitu juga terdapat hubungan antara Sikap terhadap falsafsah sains dengan Minat dan tingkah laku terhadap keusahawanan, dimana nilai $r=.386^{* *}$. Terdapat hubungan 
antara Sikap terhadap falsafsah sains dengan Sikap terhadap keusahawanan $\left(r=.386^{* *}\right)$. Terdapat hubungan antara Pengetahuan falsafah sains dengan Minat dan tingkah laku terhadap keusahawanan $\left(r=.235^{* *}\right)$. Terdapat hubungan antara Pengetahuan falsafah sains dengan Sikap terhadap keusahawanan $\left(r=.361^{* *}\right)$. Terdapat hubungan antara Minat dan tingkah laku terhadap keusahawanan dengan Sikap terhadap keusahawanan $\left(r=.470^{* *}\right)$.

Jadual 3. Pengaruh Minat dan tingkah laku terhadap falsafah sains dan Pengetahuan falsafah sains terhadap Sikap terhadap falsafsah sains

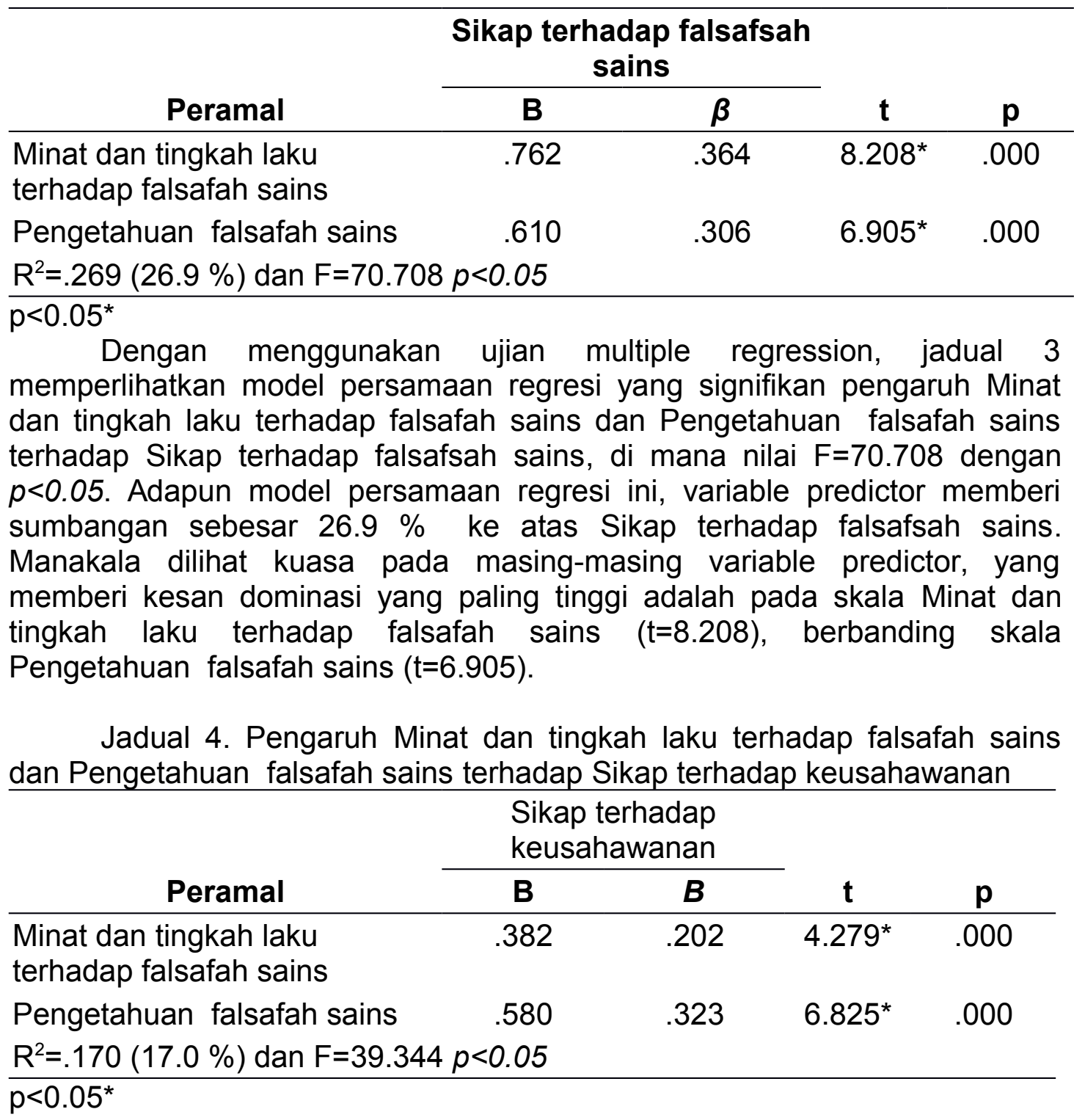


Dengan menggunakan ujian multiple regression, jadual 4 memperlihatkan model persamaan regresi yang signifikan pengaruh Minat dan tingkah laku terhadap falsafah sains dan Pengetahuan falsafah sains terhadap Sikap terhadap keusahawanan, di mana nilai $\mathrm{F}=39.344$ dengan $p<0.05$. Adapun model persamaan regresi ini, variable predictor memberi sumbangan sebesar $17.0 \%$ ke atas Sikap terhadap keusahawanan. Manakala dilihat kuasa pada masing-masing variable predictor, yang memberi kesan dominasi yang paling tinggi adalah pada skala Pengetahuan falsafah sains $(\mathrm{t}=6.825)$, berbanding skala Minat dan tingkah laku terhadap falsafah sains $(t=4.279)$.

Jadual 5. Pengaruh Minat dan tingkah laku terhadap falsafah sains dan Pengetahuan falsafah sains terhadap Minat dan tingkah laku terhadap keusahawanan

\begin{tabular}{|c|c|c|c|c|}
\hline \multirow[b]{2}{*}{ Peramal } & \multicolumn{2}{|c|}{$\begin{array}{l}\text { Minat dan tingkah } \\
\text { laku terhadap } \\
\text { keusahawanan }\end{array}$} & \multirow[b]{2}{*}{$\mathbf{t}$} & \multirow[b]{2}{*}{$\mathbf{p}$} \\
\hline & B & $B$ & & \\
\hline $\begin{array}{l}\text { Minat dan tingkah laku terhadap } \\
\text { falsafah sains }\end{array}$ & .903 & .353 & $7.497^{*}$ & .000 \\
\hline Pengetahuan falsafah sains & .410 & .168 & $3.571^{*}$ & .000 \\
\hline \multicolumn{5}{|c|}{$\mathrm{R}^{2}=.176(17.6 \%)$ dan $\mathrm{F}=40.975 p<0.05$} \\
\hline
\end{tabular}

Dengan menggunakan ujian multiple regression, jadual 5 memperlihatkan model persamaan regresi yang signifikan pengaruh Minat dan tingkah laku terhadap falsafah sains dan Pengetahuan falsafah sains terhadap Minat dan tingkah laku terhadap keusahawanan, di mana nilai $\mathrm{F}=40.975$ dengan $p<0.05$. Adapun model persamaan regresi ini, variable predictor memberi sumbangan sebesar $17.6 \%$ ke atas Minat dan tingkah laku terhadap keusahawanan. Manakala dilihat kuasa pada masing-masing variable predictor, yang memberi kesan dominasi yang paling tinggi adalah pada skala Minat dan tingkah laku terhadap falsafah sains ( $\mathrm{t}=7.497)$ berbanding skala Pengetahuan falsafah sains ( $\mathrm{t}=3.571)$.

Jadual 6. Pengaruh Sikap terhadap falsafsah sains terhadap Sikap terhadap keusahawanan 


\begin{tabular}{|c|c|c|c|c|}
\hline \multirow[b]{2}{*}{ Peramal } & \multicolumn{2}{|c|}{$\begin{array}{l}\text { Sikap terhadap } \\
\text { keusahawanan }\end{array}$} & \multirow[b]{2}{*}{$\mathbf{t}$} & \multirow[b]{2}{*}{$\mathbf{p}$} \\
\hline & B & $B$ & & \\
\hline Sikap terhadap falsafsah sains & .364 & .403 & $8.651^{*}$ & .000 \\
\hline \multicolumn{5}{|c|}{$R^{2}=.162(16.2 \%)$ dan $F=74.842 p<0.05$} \\
\hline \multicolumn{5}{|l|}{$\overline{p<0.05^{*}}$} \\
\hline \multicolumn{5}{|c|}{$\begin{array}{l}\text { Dengan menggunakan ujian multiple regression, jadual } 6 \\
\text { memperlihatkan model persamaan regresi yang signifikan pengaruh Sikap } \\
\text { terhadap falsafsah sains terhadap Sikap terhadap keusahawanan, di mana } \\
\text { nilai } F=74.842 \text { dengan } p<0.05 \text {. Adapun model persamaan regresi ini, } \\
\text { variable predictor memberi sumbangan sebesar } 16.2 \% \text { ke atas Sikap } \\
\text { terhadap keusahawanan. }\end{array}$} \\
\hline \multicolumn{5}{|c|}{$\begin{array}{l}\text { Jadual } 7 \text {. Pengaruh Sikap terhadap falsafsah sains dan Sikap terhadap } \\
\text { keusahawanan terhadap Minat dan tingkah laku terhadap keusahawanan }\end{array}$} \\
\hline & \multicolumn{2}{|c|}{$\begin{array}{l}\text { Minat dan tingkah laku } \\
\text { terhadap keusahawanan }\end{array}$} & \multirow[b]{2}{*}{$\mathbf{t}$} & \multirow[b]{2}{*}{$\mathbf{p}$} \\
\hline Peramal & B & $B$ & & \\
\hline Sikap terhadap falsafsah sains & .287 & .235 & $4.922^{*}$ & .000 \\
\hline Sikap terhadap keusahawanan & .508 & .376 & $7.880^{*}$ & .000 \\
\hline \multicolumn{5}{|c|}{$\mathrm{R}^{2}=.267(26.7 \%)$ dan $\mathrm{F}=70.193 p<0.05$} \\
\hline
\end{tabular}

Dengan menggunakan ujian multiple regression, jadual 7 memperlihatkan model persamaan regresi yang signifikan pengaruh Sikap terhadap falsafsah sains dan Sikap terhadap keusahawanan terhadap Minat dan tingkah laku terhadap keusahawan, di mana nilai $\mathrm{F}=70.193$ dengan $p<0.05$. Adapun model persamaan regresi ini, variable predictor memberi sumbangan sebesar $26.7 \%$ ke atas Minat dan tingkah laku terhadap keusahawanan. Manakala dilihat kuasa pada masing-masing variable predictor, yang memberi kesan dominasi yang paling tinggi adalah pada skala Sikap terhadap keusahawanan ( $\mathrm{t}=7.880)$ berbanding skala Sikap terhadap falsafsah sains $(\mathrm{t}=4.922)$.

Jadual 1. Perbezaan Sikap terhadap keusahawanan antara responden lelaki dan perempuan 


\begin{tabular}{lcccccc}
\hline Jantina & $\mathbf{N}$ & Min & SP & $\mathbf{d k}$ & $\mathbf{t}$ & $\mathbf{p}$ \\
\hline Lelaki & 78 & 23.31 & 3.71 & 386 & .84 & .40 \\
perempuan & 310 & 22.95 & 3.19 & & & \\
\hline pro.05
\end{tabular}

$p>0.05$

Dengan menggunakan ujian $\mathrm{t}$, dalam jadual 1 memperlihatkan tidak terdapat perbezaan Sikap terhadap keusahawanan antara responden lelaki $(\min =23.31)$ dan perempuan $(\min =22.95)$, di mana nilai $t=.84$ dengan $p>0.05$.

Jadual 2. Perbezaan Sikap terhadap keusahawanan antara responden umur 21 tahun ke bawah dan 22 tahun ke atas

\begin{tabular}{lcccccc}
\hline Tahap umur & $\mathbf{N}$ & Min & SP & $\mathbf{d k}$ & $\mathbf{t}$ & $\mathbf{p}$ \\
\hline 21 tahun ke bawah & 313 & 22.99 & 3.23 & 384 & -.38 & .71 \\
22 tahun ke atas & 73 & 23.15 & 3.50 & & & \\
\hline $\mathrm{p}>0.05$ & & & & & &
\end{tabular}

Dengan menggunakan ujian $\mathrm{t}$, dalam jadual 2 memperlihatkan tidak terdapat perbezaan Sikap terhadap keusahawanan antara responden umur 21 tahun ke bawah $(\min =22.99)$ dan 22 tahun ke atas $(\min =23.15)$, di mana nilai $t=-.38$ dengan $p>0.05$.

Jadual 3. Perbezaan Sikap terhadap keusahawanan antara responden bandar dan luar bandar

\begin{tabular}{lcccccc}
\hline Asal & $\mathbf{N}$ & Min & SP & dk & $\mathbf{t}$ & $\mathbf{p}$ \\
\hline Bandar & 216 & 22.67 & 3.24 & 386 & $-2.38^{*}$ & .018 \\
luar bandar & 172 & 23.47 & 3.33 & & &. \\
\hline p $<0.05^{*}$ & & & & & &
\end{tabular}

Dengan menggunakan ujian $\mathrm{t}$, dalam jadual 3 memperlihatkan terdapat perbezaan Sikap terhadap keusahawanan antara responden bandar $(\min =22.67)$ dan luar bandar $(\min =23.47)$, di mana nilai $t=-2.38$ dengan $p<0.05$.

Jadual 4. Perbezaan Sikap terhadap keusahawanan mengikut bangsa responden

\begin{tabular}{lrrrcc}
\hline Punca Variasi & JKD & df & MKD & F & p \\
\hline Antara Kumpulan & 100.525 & 3 & 33.508 & $3.124^{*}$ & .026 \\
Dalam Kumpulan & 4119.217 & 384 & 10.727 & & \\
Jumlah & 4219.742 & 387 & & & \\
\hline p
\end{tabular}


Dalam jadual 4 dengan menggunakan ujian ANOVA satu hala, terdapat perbezaan Sikap terhadap keusahawanan mengikut bangsa responden, melayu (Min= 23.3309, SP= 3.44606), india $(\mathrm{Min}=23.0000, \mathrm{SP}=2.85190)$ cina (Min= 22.1023, $\mathrm{SP}=2.90873$ ) dan lain-lain (Min= 22.9167, $\mathrm{SP}=$ 1.97523 ), dimana nilai $F=3.124$ dengan $p<0.05$. Adapun kumpulan yang memberi kesan perbezaan adalah antara kumpulan melayu (Min $=23.3309$, $\mathrm{SP}=3.44606)$ dan cina $(\mathrm{Min}=22.1023, \mathrm{SP}=2.90873)$.

Jadual 5. Perbezaan Sikap terhadap keusahawanan mengikut agama responden

\begin{tabular}{lrrrcc}
\hline Punca Variasi & JKD & df & MKD & F & P \\
\hline Antara Kumpulan & 100.262 & 3 & 33.421 & $3.115^{*}$ & .026 \\
Dalam Kumpulan & 4119.481 & 384 & 10.728 & & \\
Jumlah & 4219.742 & 387 & & & \\
\hline $\mathrm{p}<0.05^{*}$ & & & & &
\end{tabular}

Dalam jadual 5 dengan menggunakan ujian ANOVA satu hala, terdapat perbezaan Sikap terhadap keusahawanan mengikut agama responden, islam (Min= 23.3369, $\mathrm{SP}=3.42669)$, ,ristian $(\mathrm{Min}=22.3077, \mathrm{SP}=2.35884)$, hindu (Min= 22.7143, $\mathrm{SP}=2.72957)$ dan buddha (Min= 22.1341, SP= 2.92187 ), dimana nilai $\mathrm{F}=3.115$ dengan $p<0.05$. Adapun kumpulan yang memberi kesan perbezaan adalah antara kumpulan islam (Min $=23.3369$, $\mathrm{SP}=3.42669)$ dan buddha ( $\mathrm{Min}=22.1341, \mathrm{SP}=2.92187$ ).

Jadual 6. Perbezaan Sikap terhadap keusahawanan mengikut kelayakan akademik responden

\begin{tabular}{lrrrcc}
\hline Punca Variasi & JKD & df & MKD & F & P \\
\hline Antara Kumpulan & 77.486 & 3 & 25.829 & 2.394 & .068 \\
Dalam Kumpulan & 4142.256 & 384 & 10.787 & & \\
Jumlah & 4219.742 & 387 & & & \\
\hline p $>0.05$
\end{tabular}

$\mathrm{p}>0.05$

Dalam jadual 6 dengan menggunakan ujian ANOVA satu hala, tidak terdapat perbezaan Sikap terhadap keusahawanan mengikut kelayakan akademik responden, lulusan STPM ( $\mathrm{Min}=22.3011, \mathrm{SP}=2.95909)$, matrikulasi $(\mathrm{Min}=23.1992, \mathrm{SP}=3.39136)$, Diploma $(\mathrm{Min}=23.0000, \mathrm{SP}=$ 3.65148) dan lain-lain ( $M i n=23.9231, S P=3.12311)$, dimana nilai $F=2.394$ dengan $p>0.05$. 
Jadual 7. Perbezaan Sikap terhadap keusahawanan mengikut tahun pengajian responden

\begin{tabular}{lrrrcc}
\hline Punca Variasi & JKD & df & MKD & F & $\boldsymbol{P}$ \\
\hline Antara Kumpulan & 20.175 & 2 & 10.088 & .916 & .401 \\
Dalam Kumpulan & 4172.382 & 379 & 11.009 & & \\
Jumlah & 4192.558 & 381 & & & \\
\hline
\end{tabular}

p $>0.05$

Dalam jadual 7 dengan menggunakan ujian ANOVA satu hala, tidak terdapat perbezaan Sikap terhadap keusahawanan mengikut tahun pengajian responden, tahun 1 ( $\mathrm{Min}=22.6207, \mathrm{SP}=3.46155$ ), tahun 2 (Min= 23.1875, $\mathrm{SP}=3.17510)$ dan tahun 3 ( $\mathrm{Min}=23.0563, \mathrm{SP}=3.57326)$, dimana nilai $F=.916$ dengan $p>0.05$.

Jadual 8. Perbezaan Sikap terhadap keusahawanan mengikut latarbelakang sekolah responden

\begin{tabular}{lrrrcc}
\hline Punca Variasi & JKD & df & MKD & F & p \\
\hline Antara Kumpulan & 107.259 & 3 & 35.753 & $3.338^{*}$ & .019 \\
Dalam Kumpulan & 4112.483 & 384 & 10.710 & & \\
Jumlah & 4219.742 & 387 & & & \\
\hline P<0.05*
\end{tabular}

$\mathrm{p}<0.05^{*}$

Dalam jadual 8 dengan menggunakan ujian ANOVA satu hala, terdapat perbezaan Sikap terhadap keusahawanan mengikut latarbelakang sekolah responden, sekolah menengah $(\mathrm{Min}=23.0000, \mathrm{SP}=3.16368)$, sekolah menengah agama (Min= 24.1522, $\mathrm{SP}=4.09860)$, sekolah menengah kebangsaan ( $\mathrm{Min}=22.3483, \mathrm{SP}=2.99659)$ dan lain-lain $(\mathrm{Min}=23.5769, \mathrm{SP}=$ 3.48910 ), dimana nilai $F=3.338$ dengan $p<0.05$. Adapun kumpulan yang memberi kesan perbezaan adalah antara kumpulan sekolah menengah agama (Min= 24.1522, $\mathrm{SP}=4.09860)$ dan sekolah menengah kebangsaan (Min= 22.3483, $\mathrm{SP}=2.99659)$.

Jadual 1. Perbezaan Sikap terhadap falsafsah sains antara responden lelaki dan perempuan

\begin{tabular}{lcccccc}
\hline Jantina & $\mathbf{N}$ & $\mathbf{M i n}$ & $\mathbf{S P}$ & $\mathbf{d k}$ & $\mathbf{t}$ & $\mathbf{p}$ \\
\hline Lelaki & 78 & 30.26 & 4.03 & 386 & 1.17 & .24 \\
perempuan & 310 & 29.71 & 3.56 & & & \\
perempuan & 310 & 22.95 & 3.19 & & & \\
\hline p & & & &
\end{tabular}

$p>0.05$

Dengan menggunakan ujian $\mathrm{t}$, dalam jadual 1 memperlihatkan tidak terdapat perbezaan Sikap terhadap falsafsah sains antara responden lelaki $(\min =30.26)$ dan perempuan $(\min =29.71)$, di mana nilai $t=1.17$ dengan $p>0.05$. 
Jadual 2. Perbezaan Sikap terhadap falsafsah sains antara responden umur 21 tahun ke bawah dan 22 tahun ke atas

\begin{tabular}{lcccccc}
\hline tahap umur & $\mathbf{N}$ & Min & SP & $\mathbf{d k}$ & $\mathbf{t}$ & $\mathbf{p}$ \\
\hline 21 tahun ke bawah & 313 & 29.88 & 3.47 & 384 & .55 & .59 \\
22 tahun ke atas & 73 & 29.62 & 4.39 & & & \\
\hline
\end{tabular}

$\mathrm{p}>0.05$

Dengan menggunakan ujian $\mathrm{t}$, dalam jadual 2 memperlihatkan tidak terdapat perbezaan Sikap terhadap falsafsah sains antara responden umur 21 tahun ke bawah $(\min =29.88)$ dan 22 tahun ke atas $(\min =29.62)$, di mana nilai $t=.55$ dengan $p>0.05$.

Jadual 3. Perbezaan Sikap terhadap falsafsah sains antara responden bandar dan luar bandar

\begin{tabular}{llcccccc}
\hline Pembolehubah & Asal & N & Min & SP & dk & t & p \\
\hline Sikap terhadap & bandar & 216 & 29.04 & 3.58 & 386 & -4.89 & .000 \\
falsafsah sains & luar bandar & 172 & 30.81 & 3.52 & & & \\
\hline
\end{tabular}
$\mathrm{p}<0.05^{*}$

Dengan menggunakan ujian $\mathrm{t}$, dalam jadual 3 memperlihatkan terdapat perbezaan Sikap terhadap falsafsah sains antara responden bandar $(\min =29.04)$ dan luar bandar $(\min =30.81)$, di mana nilai $t=-4.89$ dengan $p<0.05$.

Jadual 4. Perbezaan Sikap terhadap falsafsah sains mengikut bangsa responden

\begin{tabular}{lcrrcc}
\hline Punca Variasi & JKD & Df & MKD & F & p \\
\hline Antara Kumpulan & 1366.151 & 3 & 455.384 & 45.874 & $.000^{*}$ \\
Dalam Kumpulan & 3811.931 & 384 & 9.927 & & \\
Jumlah & 5178.082 & 387 & & & \\
\hline
\end{tabular}

$\mathrm{p}<0.05^{*}$

Dalam jadual 4 dengan menggunakan ujian ANOVA satu hala, terdapat perbezaan Sikap terhadap falsafsah sains mengikut bangsa responden, melayu (Min= 31.0294, SP= 3.31482), india $(\mathrm{Min}=27.0000, \mathrm{SP}=2.50333)$, cina $(\mathrm{Min}=26.7500, \mathrm{SP}=2.65334)$ dan lain-lain $(\mathrm{Min}=28.8333, \mathrm{SP}=$ 3.40677 ), dimana nilai $\mathrm{F}=45.874$ dengan $p<0.05$. Adapun kumpulan yang memberi kesan perbezaan adalah antara kumpulan melayu (Min $=31.0294$, $\mathrm{SP}=3.31482)$ dan india $(\mathrm{Min}=27.0000, \mathrm{SP}=2.50333)$, serta antara kumpulan melayu (Min= 31.0294, $\mathrm{SP}=3.31482)$ dan cina $(\mathrm{Min}=26.7500, \mathrm{SP}=2.65334)$. Jadual 5. Perbezaan Sikap terhadap falsafsah sains mengikut agama responden 


\begin{tabular}{lrrrcc}
\hline Punca Variasi & JKD & df & MKD & F & p \\
\hline Antara Kumpulan & 1434.917 & 3 & 478.306 & $49.068^{*}$ & .000 \\
Dalam Kumpulan & 3743.166 & 384 & 9.748 & & \\
Jumlah & 5178.082 & 387 & & & \\
\hline
\end{tabular}

$\mathrm{p}<0.05^{*}$

Dalam jadual 5 dengan menggunakan ujian ANOVA satu hala, terdapat perbezaan Sikap terhadap falsafsah sains mengikut agama responden, islam (Min= 31.0108, $\mathrm{SP}=3.32148)$, kristian $(\mathrm{Min}=28.3077, \mathrm{SP}=2.83974)$, hindu (Min= 27.0714, $\mathrm{SP}=2.52569$ ) dan buddha (Min= 26.5000, SP= 2.47581 ), dimana nilai $\mathrm{F}=49.068$ dengan $p<0.05$. Adapun kumpulan yang memberi kesan perbezaan adalah antara kumpulan islam $(\mathrm{Min}=31.0108$, $\mathrm{SP}=3.32148)$ dan kristian $(\mathrm{Min}=28.3077, \mathrm{SP}=2.83974)$, serta antara kumpulan islam (Min= 31.0108, $\mathrm{SP}=3.32148)$ dan hindu (Min= 27.0714, $\mathrm{SP}=2.52569$ ).

Jadual 6. Perbezaan Sikap terhadap falsafsah sains mengikut kelayakan akademik responden

\begin{tabular}{lrrrcc}
\hline Punca Variasi & JKD & df & MKD & F & p \\
\hline Antara Kumpulan & 1189.602 & 3 & 396.534 & $38.177^{*}$ & .000 \\
Dalam Kumpulan & 3988.480 & 384 & 10.387 & & \\
Jumlah & 5178.082 & 387 & & & \\
\hline
\end{tabular}

$\mathrm{p}<0.05^{*}$

Dalam jadual 6 dengan menggunakan ujian ANOVA satu hala, terdapat perbezaan Sikap terhadap falsafah sains mengikut kelayakan akademik responden, lulusan STPM ( $\mathrm{Min}=26.7527, \mathrm{SP}=2.68108$ ), matrikulasi (Min= 30.7031, SP= 3.39402), Diploma (Min= 30.3846, SP= 3.50092) dan lain-lain $(\mathrm{Min}=31.8846, \mathrm{SP}=3.11547$ ), dimana nilai $\mathrm{F}=38.177$ dengan $p<0.05$. Adapun kumpulan yang memberi kesan perbezaan adalah antara kumpulan STPM $(\mathrm{Min}=26.7527, \mathrm{SP}=2.68108)$ dan matrikulasi $(\mathrm{Min}=30.7031, \mathrm{SP}=3.39402)$ serta antara kumpulan STPM $(\mathrm{Min}=26.7527, \mathrm{SP}=2.68108)$ dan Diploma $(\mathrm{Min}=30.3846, \mathrm{SP}=3.50092)$.

Jadual 7. Perbezaan Sikap terhadap falsafsah sains mengikut tahun pengajian responden

\begin{tabular}{lrrrcc}
\hline Punca Variasi & JKD & df & MKD & F & p \\
\hline Antara Kumpulan & 182.076 & 2 & 91.038 & $7.004^{*}$ & .001 \\
Dalam Kumpulan & 4926.521 & 379 & 12.999 & & \\
Jumlah & 5108.597 & 381 & & & \\
\hline
\end{tabular}

p $<0.05^{*}$ 
Dalam jadual 7 dengan menggunakan ujian ANOVA satu hala, terdapat perbezaan Sikap terhadap falsafah sains mengikut tahun pengajian responden, tahun 1 (Min= 31.0575, SP= 3.56780), tahun $2(\mathrm{Min}=29.5759$, $\mathrm{SP}=3.54264)$ dan tahun 3 (Min= 29.1127, $\mathrm{SP}=3.84169$ ), dimana nilai $\mathrm{F}=7.004$ dengan $p<0.05$. Adapun kumpulan yang memberi kesan perbezaan adalah antara kumpulan tahun $1(\mathrm{Min}=31.0575, \mathrm{SP}=3.56780)$ dan tahun 2 (Min= 29.5759, SP= 3.54264), serta antara kumpulan tahun 1 (Min= $31.0575, \mathrm{SP}=3.56780)$ dan tahun $3(\mathrm{Min}=29.1127, \mathrm{SP}=3.84169)$.

Jadual 8. Perbezaan Sikap terhadap falsafsah sains mengikut latarbelakang sekolah responden

\begin{tabular}{lrrrcc}
\hline Punca Variasi & JKD & df & MKD & F & p \\
\hline Antara Kumpulan & 561.819 & 3 & 187.273 & $15.578^{*}$ & .000 \\
Dalam Kumpulan & 4616.264 & 384 & 12.022 & & \\
Jumlah & 5178.082 & 387 & & & \\
\hline $\mathbf{p}<0.05^{*}$ & & & & &
\end{tabular}

Dalam jadual 8 dengan menggunakan ujian ANOVA satu hala, terdapat perbezaan Sikap terhadap falsafsah sains mengikut latarbelakang sekolah responden, sekolah menengah $(\mathrm{Min}=29.9251, \mathrm{SP}=3.50961)$, sekolah menengah agama ( $\mathrm{Min}=32.2174, \mathrm{SP}=3.46354)$, sekolah menengah kebangsaan $(\mathrm{Min}=28.0674, \mathrm{SP}=3.36357)$ dan lain-lain $(\mathrm{Min}=30.7308, \mathrm{SP}=$ 3.44741 ), dimana nilai $F=15.578$ dengan $p<0.05$. Adapun kumpulan yang memberi kesan perbezaan adalah antara kumpulan sekolah menengah (Min= 29.9251, $\mathrm{SP}=3.50961)$ dan sekolah menengah agama $(\mathrm{Min}=32.2174, \mathrm{SP}=$ 3.46354 ) serta antara kumpulan sekolah menengah (Min= 29.9251, SP= 3.50961 ) dan sekolah menengah kebangsaan ( $\mathrm{Min}=28.0674, \mathrm{SP}=3.36357$ ).

Jadual 1. Perbezaan Minat dan tingkah laku terhadap keusahawanan antara responden lelaki dan perempuan

\begin{tabular}{lcccccc}
\hline Jantina & $\mathbf{N}$ & Min & SP & $\mathbf{d k}$ & $\mathbf{t}$ & $\mathbf{p}$ \\
\hline lelaki & 78 & 32.33 & 4.70 & 386 & 1.31 & .19 \\
perempuan & 310 & 31.59 & 4.41 & & & \\
\hline Pro.05u
\end{tabular}

$p>0.05$

Dengan menggunakan ujian $\mathrm{t}$, dalam jadual 1 memperlihatkan tidak terdapat perbezaan Minat dan tingkah laku terhadap keusahawanan antara responden lelaki $(\min =32.33)$ dan perempuan $(\min =31.59)$, di mana nilai $\mathrm{t}=1.31$ dengan $p>0.05$. 
Jadual 2. Perbezaan Minat dan tingkah laku terhadap keusahawanan antara responden umur 21 tahun ke bawah dan 22 tahun ke atas

\begin{tabular}{lcccccc}
\hline Tahap umur & $\mathbf{N}$ & Min & SP & Dk & T & P \\
\hline 21 tahun ke bawah & 313 & 31.72 & 4.49 & 384 & -.09 & .93 \\
22 tahun ke atas & 73 & 31.77 & 4.36 & & & \\
\hline$p>0.05$
\end{tabular}
$\mathrm{p}>0.05$

Dengan menggunakan ujian $\mathrm{t}$, dalam jadual 2 memperlihatkan tidak terdapat perbezaan Minat dan tingkah laku terhadap keusahawanan antara responden umur 21 tahun ke bawah $(\min =31.72)$ dan 22 tahun ke atas ( $\min =31.77$ ), di mana nilai $t=-.09$ dengan $p>0.05$.

Jadual 3. Perbezaan Minat dan tingkah laku terhadap keusahawanan antara responden bandar dan luar bandar

\begin{tabular}{lcccccc}
\hline Asal & $\mathbf{N}$ & Min & SP & Dk & t & P \\
\hline bandar & 216 & 31.34 & 4.34 & 386 & -1.97 & .050 \\
luar bandar & 172 & 32.24 & 4.59 & & & \\
\hline p $<0.05^{*}$ & & & & & &
\end{tabular}

Dengan menggunakan ujian $\mathrm{t}$, dalam jadual 3 memperlihatkan tidak terdapat perbezaan Minat dan tingkah laku terhadap keusahawanan antara responden bandar $(\min =31.34)$ dan luar bandar $(\min =3.24)$, di mana nilai $t=-$ 1.97 dengan $p>0.05$.

Jadual 4. Perbezaan Minat dan tingkah laku terhadap keusahawanan mengikut bangsa responden

\begin{tabular}{lrrrcc}
\hline Punca Variasi & JKD & df & MKD & F & P \\
\hline Antara Kumpulan & 163.146 & 3 & 54.382 & $2.760^{*}$ & .042 \\
Dalam Kumpulan & 7567.562 & 384 & 19.707 & & \\
Jumlah & 7730.709 & 387 & & & \\
\hline p $<0.05^{*}$ & & & & &
\end{tabular}

Dalam jadual 4 dengan menggunakan ujian ANOVA satu hala, terdapat perbezaan Minat dan tingkah laku terhadap keusahawanan mengikut bangsa responden, melayu (Min= 32.1250, $\mathrm{SP}=4.62296)$, india $(\mathrm{Min}=30.9375, \mathrm{SP}=$ $3.67820)$, cina $(\mathrm{Min}=30.6250, \mathrm{SP}=4.08055)$ dan lain-lain $(\mathrm{Min}=32.2500$, $\mathrm{SP}=3.36087$ ), dimana nilai $\mathrm{F}=2.760$ dengan $p<0.05$. Adapun kumpulan yang memberi kesan perbezaan adalah antara kumpulan melayu (Min $=32.1250$, $\mathrm{SP}=4.62296)$ dan cina $(\mathrm{Min}=30.6250, \mathrm{SP}=4.08055)$. 
Jadual 5. Perbezaan Minat dan tingkah laku terhadap keusahawanan mengikut agama responden

\begin{tabular}{lrrrcc}
\hline Punca Variasi & JKD & df & MKD & F & $\boldsymbol{P}$ \\
\hline Antara Kumpulan & 143.151 & 3 & 47.717 & $2.415^{*}$ & .066 \\
Dalam Kumpulan & 7587.557 & 384 & 19.759 & & \\
Jumlah & 7730.709 & 387 & & & \\
\hline P & & & & &
\end{tabular}

p $<0.05^{*}$

Dalam jadual 5 dengan menggunakan ujian ANOVA satu hala, tidak terdapat perbezaan Minat dan tingkah laku terhadap keusahawanan mengikut agama responden, islam ( $\mathrm{Min}=19.1362, \mathrm{SP}=1.74943)$, kristian (Min= 18.8462, SP= 1.67562), hindu(Min= 18.3571, $S P=2.09788)$ dan buddha (Min= 18.3780, $S P=1.99159$ ), dimana nilai $F=2.415$ dengan $p>0.05$. Jadual 6. Perbezaan Minat dan tingkah laku terhadap keusahawanan mengikut kelayakan akademik responden

\begin{tabular}{lrrrcc}
\hline Punca Variasi & JKD & df & MKD & F & P \\
\hline Antara Kumpulan & 133.813 & 3 & 44.604 & 2.255 & .082 \\
Dalam Kumpulan & 7596.895 & 384 & 19.784 & & \\
Jumlah & 7730.709 & 387 & & & \\
\hline p $>0.05$ & & & & &
\end{tabular}

Dalam jadual 6 dengan menggunakan ujian ANOVA satu hala, tidak terdapat perbezaan Minat dan tingkah laku terhadap keusahawanan mengikut kelayakan akademik responden, lulusan STPM (Min= 30.9355, SP= 4.20353), matrikulasi (Min= 31.9766, SP= 4.61619), Diploma (Min= 33.7692, $\mathrm{SP}=3.46780)$ dan lain-lain $(\mathrm{Min}=31.2692, \mathrm{SP}=3.96543)$, dimana nilai $\mathrm{F}=2.255$ dengan $p>0.05$.

Jadual 7. Perbezaan Minat dan tingkah laku terhadap keusahawanan mengikut tahun pengajian responden

\begin{tabular}{lrrrcc}
\hline Punca Variasi & JKD & df & MKD & F & p \\
\hline Antara Kumpulan & 190.550 & 2 & 95.275 & $4.808^{*}$ & .009 \\
Dalam Kumpulan & 7510.245 & 379 & 19.816 & & \\
Jumlah & 7700.796 & 381 & & & \\
\hline
\end{tabular}

$\mathrm{p}<0.05^{\star}$

Dalam jadual 7 dengan menggunakan ujian ANOVA satu hala, terdapat perbezaan Minat dan tingkah laku terhadap keusahawanan mengikut tahun pengajian responden, tahun1 $(\mathrm{Min}=31.0575, \mathrm{SP}=4.73325)$, tahun $2(\mathrm{Min}=$ 
32.3527, $\mathrm{SP}=4.25063)$ dan tahun $3(\mathrm{Min}=30.7746, \mathrm{SP}=4.71229)$, dimana nilai $\mathrm{F}=4.808$ dengan $p<0.05$. Adapun kumpulan yang memberi kesan perbezaan adalah antara kumpulan tahun $2(\mathrm{Min}=32.3527, \mathrm{SP}=4.25063)$ dan tahun $3(\mathrm{Min}=30.7746, \mathrm{SP}=4.71229)$.

Jadual 8. Perbezaan Minat dan tingkah laku terhadap keusahawanan mengikut latarbelakang sekolah responden

\begin{tabular}{lrrrcc}
\hline Punca Variasi & JKD & df & MKD & F & P \\
\hline Antara Kumpulan & 164.095 & 3 & 54.698 & $2.776^{*}$ & .041 \\
Dalam Kumpulan & 7566.613 & 384 & 19.705 & & \\
Jumlah & 7730.709 & 387 & & & \\
\hline p $<0.05^{*}$ & & & & &
\end{tabular}

Dalam jadual 8 dengan menggunakan ujian ANOVA satu hala, terdapat perbezaan Minat dan tingkah laku terhadap keusahawanan mengikut latarbelakang sekolah responden, sekolah menengah (Min= 31.5198, SP= 4.28450), sekolah menengah agama ( $M i n=33.3478, S P=4.50786)$, sekolah menengah kebangsaan $(\mathrm{Min}=31.2584, \mathrm{SP}=4.75903)$ dan lain-lain (Min= 32.4615, $\mathrm{SP}=4.51868$ ), dimana nilai $\mathrm{F}=2.776$ dengan $p<0.05$. Adapun kumpulan yang memberi kesan perbezaan adalah antara kumpulan sekolah menengah agama (Min= 33.3478, SP= 4.50786) dan sekolah menengah kebangsaan $(\mathrm{Min}=31.2584, \mathrm{SP}=4.75903)$.

\section{Kesimpulan}

Kajian ini diharapakan dapat membantu pelajar mencapai apa yang diinginkan dari mata kuliah STPD2013 sejarah dan falsafah sains, di mana kursus ini mensasarkan agar pelajar mampu membincangkan asas falsafah yang mencorakkan skop perkembangan dan pembangunan ilmu dan kaedah ilmu sains itu berkembang, bagaimana ilmu sains bermula dan bagaimana pula Tanya digunakan dalam menyelesaikan masalah semasa. Kursus ini juga menyajikan kepada para pelajar bagaimana ilmu dikembangkan dalam pelbagai peradaban dan hubungan ilmu sains kini dengan ilmu sains masa lalu. Pendekatan yang digunakan dalam membentangkan kursus ini adalah secara kronologi dan tematik, bermula dengan epistemologi dan kaedah sains, diikuti dengan sejarah pertumbuhan tamadun, tinjauan aspek etika kemasyarakatan dan budaya S\&T, institusi S\&T dalam negara dan dasar S\&T bagi tujuan pembangunan S\&T dan pemindahan teknologi.

Demikian pula kajian ini juga diharapakan dapat membantu pelajar mencapai apa yang diinginkan dari mata kuliah STPD2023 Etika dalam kegiatan sains dan teknologi, yang mana kursus ini mensasarkan agar 
pelajar termotivasikan untuk memperbaiki perkembangan Sains dan Teknologi Moden, yang ditakrifkan sebagai sekular dan menyebabkan barlakunya malapetaka kepada alam dan manusia, maka pemikirpemikir Barat sendiri mengusulkan agar subjek etika dimasukkan dalam silabus Sains dan Teknologi Moden di universiti. Matlamatnya adalah untuk membimbing aktiviti-aktiviti ahli-ahli sains dan teknologi. Sebagai tambahan kepada kandungan asal kursus etika yang diambil daripada bukubuku karangan sarjana-sarjana Tamadun Barat Moden menghayati pengsekularan, yang sepatutnya dipinggirkan langsung daripada masyarakat Malaysia yang beragama, maka penyuburan kepada penyatuan ilmu sepatutnya diwujudkan. Itulah sebabnya etika yang diamalkan oleh pelbagai tradisi masyarakat Malaysia perlulah dikuliahkan juga. Oleh yang demikian, kuliah-kuliah etika yang berlatarbelakangkan Islam, Kristian, Buddha, Hindu malah Ananisme Aslian diumpukkan sebagai bahan-bahan kuliah. Diharapkan nanti mahasiswa/i yang terhasil mampu untuk merumuskan penyatuan ilmu yang lebih balk daripada yang pernah dihasilkan oleh sarjana-sarjana beragama sebelum ini.

Dan kajian ini memiliki satu kegunaan yang penting adalah membantu untu mengukuhkan Kursus STPD 2213 Keusahawanan sains dan teknologi, sebagai bekal untuk pelajar mengenal konsep, teori dan kemahiran asas keusahawanan dan penginnovasian hasil $R$ \& $D$ dalam $S$ \& $T$, menerangkan peranan $S \& T$ dan saintis dalam pengurusan, pengeluaran produk secara lebih saintifik dan dalam pembangunan industri yang berlatarbelakangkan ekonomi ilmu. Kursus juga menjelaskan kepada pelajar sains fahaman teori, konsep-konsep asas organisasi, pengurusan dan kegiatan keusahawanan, Kursus turut memberi peluang kepada pelajar membina perhubungan di antara industri dengan universiti melalui tugasan berkumpulan yang melibatkan para pelajar berinteraksi dengan saintis dan usahawan saintis tempatan yang mempunyai industri sendiri.

\section{Daftar Pustaka}

Abd Rafie. 2002. Hala tuju dan polisi : Pendidikan sains dan pembangunan Negara. Kertas kerja seminar pendidikan sains. Universiti Malaya. Kulala Lumpur 16 Februari.

American association for advancement of sciences (AAAS). 1989. Scinces for all Americans. Washington DC.

Cartes, W.M. 1985. A practical guide to educational research. New Jersey: Prentice Hall. 
Cholid Narbuko \& Abu Achmadi. 1997. Metodologi penelitian. Jakarta: Bumi Aksara.

Cross, RT \& Price, RF. 1992. Teaching sciences for all responsibility. Sidney: St. Louis Press

Gay, L. R., \& Airasian, P. 2000. Educational Research Competencies For Analysis and Application. Ed. Ke-6. New Jersey: Prentice-Hall, Inc.

Hashim Yaacob, and Abdul Jalil Othman. 2007. Dunia Pendidikan Dalam EraGlobalisasi : Peranan Dan Cabaran. Jurnal Masalah Pendidikan, 30 (1).

Haynes, NM. 2001. Positive school climate is more than "feel good" school development program. Newsline. http//info.med.yale.edu/comer/feelgood.html. (20 January 2002)

Ibrahim Muhamad. 2010. Buku Program. Sambutan Hari Pendidik MARA 2010

James, H.M.N. 2004. Education Research. Boston: Pearson Education Inc.

Khalid Johari. 2003. Penyelidikan Dalam Pendidikan (Konsep dan Prosedur). Malaysia: Prentice Hall.

Lilia Halim, Kamisah Osman \& Zanaton Hj. Iksan. 2002. Perkaitan di antara sikap saintifik terhadap sains di kalnagan pelajar sekolah menengah. Laporan penyelidikan jangka pendek. Fakulti pendidikan. Universiti Kebangsaan Malaysia, Kuala Lumpur

Lilia Halim, Nor Aishah Buang, Khalijah Mohd. Salleh. 2003. Projek Arus Perdana 11 AP1/2000 oleh pensyarah Fakulti Pendidikan UKM 2003.

Mingguan Malaysia, 28 Mac 2010

Mohammad Najib Abdul Ghafar. 1999. Penyelidikan pendidikan. Johor: Penerbit Universiti Teknologi Malaysia.

Mohammad Shffie Abu Bakar. 1991. Metodologi penyelidikan. Bangi: Penerbit Universiti Kebangsaan Malaysia.

Mohd. Azhar, Abd. Hamid Zainudin Hassan, Esa Khalid ,Othman Abd Kassim. (2003).Pendidik Kreatif Sebagai Teras Transformasi Literasi Kreatif di 
Malaysiahttp//www Eprints.Utm.My/.../ Pendidik Kreatif Sebagai Teras Transformasi.Pdf .[18 September 2009].

Moore, S.W. 1983. Developing And Educating Educational Research. Boston: Litle Brown Company.

Nor Aishah Buang. 2001. Creativity, design, innovation and entrepreneurship education orientation in vocational and technical curriculum; Towards global challenges. DIm. Buang, Halim, Mohd Yasin, Mustapha, Mohd Noor \& $\mathrm{Haq}($ Pyt.) Proceeding of Technology and Vocational-Technical Education: Gllobalization and Future Trends, 12-13 November.

Peter, A. And Anne, T.2000. Enterpreneurship In Science: Casestudies Form Liquid Cystal Application. Pormetheus.Vol. 18 Issue 2, 13-148.

Pintrich, PR. 2003. A motivational science perspective on the role of student motivational theory and research. Educational psychologist. 95 (4). 667-680.

Poedjiadi, A. 1990. "partisipasi FMIFA IKIP Bandung dalam menunjang perkembangan pendidikan sains dan teknologi dewasa ini", Makalah disajikan pada seminar staf FMIPA IKIP Bandung. Bandung, 3 mei.

Poh Swee Hiang. 1997. Pedigogi sains kemahiran proses sains. Kuala Lumpur Kumpulan Budiman. Sdn . Bhd.

Renzulli, J. S.Rizza \& Smith. 2002. Learning Styles Inventory Version III. A Measure Of Student Preference For Instructional Techniques Technical And Administration anual.Mansfield Center CT: Creative Learning Press.

Robiah Sidin. 1998. Report Of The Study, Socialisation For Science And Technology: The Case Of Education And Training For Malaysian Youths. Faculty Of Education, UKM,Bangi.

Samsudin A. Rahim et al. 2006. Indeks Belia Malaysia. Putra Jaya: Institut Penyelidikan Pembangunan Belia Malaysia (IPPBM).

Sekaran, U. 2000. Research method for business. Ed. Ke-3. New York : Jhon Willey and Sons

Shahabuddin Hashim, Rohizani Yaakub dan Mohd Zohir Ahmad. 2003. "pedagogi (strategi dan tekhnik mengajar dengan berkesan)". Pahang : PTS Publication 
Sukmadinata. 1997. Pengembangan kurikulum : teori dan praktek. Bandung: Remaja Rosdakarya

Sulaiman Ngah Razali. 1996. Analisis Data Dalam Penyelidikan Pendidikan. Kuala Lumpur: Dewan Bahasa Pustaka.

Tuckman, Bruce W. 1978. Analyzing social educational research data. London: Mc Graw Hill Book co.

William, W. 2000. Research methods in Education. Boston: A Person Education Company

Yager, RE. 1992. Science technology-society as reform, ICASE YEARBOOK, 2.

Zurida Ismail, Syarifah Norhaidah Syed Idros \& Mohd. Ali Samsudin. 2005. "kaedah mengajar sains". Bentong : PTS Profesional 